Int. Archs Allergy appl. Immun. 1978;57:I-VI

\title{
Contents, Vol. 57, 1978
}

Vol. 57,1978

International Archives of Allergy and Applied Immunology

Founded 1950 by: D. Harley, P. Kallós, W. Löffler and F. W. Wittich Continued by: E. A. Brown (1952-1954), W. Kaufman (1955-1967), F. Hahn (1961-1972), H. C. Goodman (19631975)

Editor s-in- Chief:

R. R. A. Coombs, Cambridge L. M. Lichtenstein, Baltimore, Md.

Contributing Editors:

G. Andres, Buffalo, N.Y.

E. L.Becker, Farmington, Conn.

W. E. Brocklehurst, Windlesham

A. Cerletti, Basel

B. Diamant, Copenhagen

P. Dukor, Basel

W. P. Faulk, Charleston, S.C.

M. Feldman, Rehovot

H. Fischer, Freiburg-Zähringen

R. van Furth, Leiden

P. G. H. Gell, Birmingham

H. Gewurz, Chicago, Ill.

I. Glazer, Tel Aviv

R. A. Good, New York, N.Y.

F. Hahn, Wittnau

L. Å. Hanson, Göteborg

P. Kallós, Helsingborg F. Milgrom, Buffalo, N.Y.

M. Hess, Bern

L. Hudson, Beckenham

H. Isliker, Lausanne

S. G. O. Johansson, Uppsala

E. A. Kabat, New York, N.Y.

K. Kano, Buffalo, N.Y.

R. Keller, Zurich

Ö. Ouchterlony, Göteborg

Z. Ovary, New York, N.Y.

P. Perlmann, Stockholm

E. Pick, Tel Aviv

K. W. Pondman, Amsterdam

R. E. Reisman, Buffalo, N.Y. 
M. Roitt, London

K. Rother, Heidelberg

Z. Trnka, Basel G. B. West, Epsom

D. S. Rowe, Lausanne

H. D. Schlumberger, Wuppertal A. Sehon, Winnipeg

E. Sorkin, Davos Platz

H. Storck, Zurich

A. Szenberg, Melbourne

A. Szentivanyi, Tampa, Fla.

T. B. Tomasi, jr., Rochester, Minn.

G. Torrigiani, Geneve

J. L. Turk, London

E. R. Unanue, Boston, Mass.

G. A. Voisin, Paris

B.H. Waksman, New Haven, Conn.

A. L. de Week, Bern

G. Wick, Innsbruck

S.Karger $\cdot$ Basel $\cdot$ München $\cdot$ Paris $\cdot$ London $\cdot$ New York $\cdot$ Sydney

All rights reserved.

No part of this publication may be translated into other languages, reproduced or utilized in any form or by any means, electronic or mechanical, including photocopying, recording, microcopying, or by any information storage and retrieval system, without permission in writing from the publisher.

(C) Copyright 1978 by S. Karger AG, 4011 Basel (Switzerland), Arnold-Böcklin-Strasse 25

Printed in Switzerland by Buchdruckerei National-Zeitung + Basler Nachrichten AG, Basel

Contents Vol. 57,1978

No. 1

Original Paper

Moore, V. L.; Johnson, L. L., and Stevens, J. O.:

Cell-Mediated Immunity in the Lungs of

Rabbits Using Conjugated Proteins 1

Blackwood, L. L., and Molinari, J. A.: Effect of Trichinella spiralis Infection on Delayed Hypersensitivity to Heterologous Antigens .... 8

Blomgren, H. and Larsson, E.-L.: Regulation of Lymphocyte Proliferation by Soluble Products

Release by Stimulated Human Lymphocytes . 15

Furuya, K. and L.'rasawa, S.: Demonstration of

Antibodies to Chlorophenothiazine Deriva

tives 22

Créau-Goldberg, N. and Salomon, J.-C.: Thymo-

independent Antigenic Stimulation in Nude

Mice: Response to Polyvinylpyrrolidone and

Adjuvant Effects of Corynebacterium parvum

andLHl 
Akoglu, T.; Trenchev, P., and Holborow, E. J.: An Effect of Actin on Cell Migration 37

Nomoto, D.; Imada, Y.; Muraoka, S., and Takeya, K.: Relationships between IgE Anti body Production and Other Immune Respon ses. II. Effect of Thymectomy at Various Times after Birth 43

Jones, W. O.; Rothwell, T.L.W., and Adams, D. B.: Studies on the Role of Histamine and 5Hydroxytryptamine in Immunity against the Nematode Trichoslrongylus colubriformis. V. Changes in Amine Levels in the Intestine fol lowing Infection of Guinea Pigs of Different Immune Status 48

Forrester, P. I.; Lai, P. C. W.; Hancock, R. L.; Hay, D. M., and Lorscheider, F. L.: Hetero logous Radíoimmunoassay of Monkey $\alpha$-Fetoprotein 57

Babiuk, L. A. and Rouse, B. T.: Interactions be tween Effector Cell Activity and Lymphokines: Implications for Recovery from Herpesvirus Infections 62

Melendro, E. I.; Contreras, M. F.; Ximénez, C.; García-Maynez, A. M., and Ortiz-Ortiz, L.: Changes in Host Resistance Caused by Nocardia brasiliensis in Mice: Cross-Protection against Listeńa monocytugenes 74 Herrlinger, J. D. and Müller-Ruchholtz, W.: Dif ferent Suppressive Effects of Combined Cyclophosphamide-Antigen Treatment Compared with Exclusive Cyclophosphamide Treatment on Primary and Secondary Humoral Immune Reactivity 82

Cahill, R. N. P.; Poskitt, D. C.; Frost, H.; Julius, M. H., and Trnka, Z.: Behaviour of SheepImmunoglobulin-Bearing and Non-Immunoglobulin-Bearing Lymphocytes Isolated by Nylon Wool Columns 90

No. 2

Michael Heidelberger 97

Original Paper

Graybill, J. R. and Taylor, R. L.: Host Defense in Cryptococcosis. I. An in vivo Model for Evaluating Response 101

IV

Contents 
Søeberg, B.; Sumerska, T.; Binns, R. M., and

Balfour, B. M.: Contact Sensitivity in the Pig.

II. Induction by Intralymphatic Infusion of

DNP Conjugated Cells 114

Neveu, P. J.: Suppression of Delayed Hyper-

sensitivity to the Hapten by Induction of To

lerance to the Carrier 126

Ogita, T.; Okudaira,H.; Tadokoro, K.; Suko, M.; Mizushima, Y.; Gohda, A., and Hori-uchi, Y.:

Antibody Formation to Double-Stranded DNA in nu/nu and nu/+ Mice ... 130

Poole, A. R.; Oldham, G., and Coombs, R. R. A.:

Early Rheumatoid-Like Lesions in Rabbits

Injected with Foreign Serum: Relationship to

Localization of Immune Complexes in the

Lining Tissues of Joints and Cellular Content

of Synovial Fluid

135

Patkar, S. A.; Kazimierczak, W., and Diamant, B.: Histamine Release by Calcium from Sodium

Fluoride-Activated Rat Mast Cells. Further Evidence for a Secretory Process ... 146

Mancino, D. and Bevilacqua, N.: Persistent and

Boosterable IgE Antibody Production in Mice

Injected with Low Doses of Ovalbumin and

Silica 155

Boot, J. R.; Cockerill, A. F.; Dawson, W.; Mal-

len, D. N. B., and Osborne, D. J.: Modifica

tion of Prostaglandin and Thromboxane Re

lease by Immunological Sensitisation and

Successive Immunological Challenges from

Guinea-Pig Lung 159

Todd, G. and Dowdle, E. B.: Neutrophil Chemo-

taxis: the Kinetics of Cellular Locomotion in

vitro 165

Tonkin, C. H. and Brostoff, J.: Do Fatty Acids

Exert a Specific Effect on Human Lymphocyte

Transformation in vitro? 171

Gold, E. F. and Ben-Efraim, S.: Selective Killing

of Mitogen-Induced Transformed Cells by

Quinine Sulfate in vitro 177

Aukrust, L.; Grimmer, 0., and Aas, K.: Demon

stration of Distinct Allergens by Means of

Immunological Methods. Comparison of

Crossed Radioimmunoelectrophoresis, Ra-

dioallergosorbent Test and in vivo Passive

Transfer Test 183

Varia 192

No. 3

Original Paper 
Eggleston, P. A.; Hendley, J. O.; Gwaltney, J. M., jr.; Eggleston, A. W., and Leavell, B. S., jr.:

Histamine in Nasal Secretions 193

Kermani-Arab, V.; Roberts, J. L., and Leslie, G.

A.: Structure and Biological Function of $\mathrm{Hu}$

man IgD. XVI. T and B Lymphocytes in Pity-

riasis rosea 201

Uotila, A.; Hamblin, A.; Dumonde, D. C, and Krohn,K.J.E.: The Effect of Transfer Factor on Lymphocyte Transformation. Comparison of Augmentation by Dialysates of Leukocytes and Lymphoid and Non-Lymphoid Organs . 210

Nagaki, K; lida, K.; Okubo, M., and Inai, S.: Reaction Mechanisms of /?1H Globulin .... 221

Lin, T.-H.; Sperling, F.; Lin, T.-M., and Halbert,

S. P.: Pregnancy-Associated Plasma Proteins

in Pregnant and Pseudopregnant Rats 233

Lambert, R. M.; Dolan, J. R., and Zelenski, K.

R.: The H, HI, I and i Blood Group Antigens

in Butanol Extracts of Rabbit Tissues

Agrawal, C. G.; Gupta, S. P.; Chaturvedi, U. C.;

Mitra, M. K.; Gupta, N. N., and Gupta, S.:

T Lymphocytes and Anticardiac Antibodies in

Patients with Ischemic Heart Diseases 246

Aukrust, L.; Apold, J.; Elasyed, S., and Aas, K.: Crossed Immunoelectrophoretic and Crossed Radioimmunoelectrophoretic Studies Employing a Model Allergen from Codfish .... 253

Sheena, J. and Meade, C. J.: Mice Bearing the ob/ob Mutation Have Impaired Immunity .. 263

Zuckerman, S. H. and Douglas, S. D.: Optimal

Conditions for Fc Receptor-Ligand Inter

action 269

Futrell, J. M. and Morgan, P. N.: Inhibition of

Human Complement Components by Loxos-

ceies reciusa Venom 275

Short Communication

Okazaki,T.; Johnson,T.F.; Reisman,R.E.; Ar-

besman, C. E., and Míddleton, E.,jr.: Plasma

Prostaglandin Concentrations in Allergic

Bronchial Asthma 279

Contents

$\mathrm{V}$

Nomenclature for Factors of the HLA Sys

tem - $1977 \quad 282$

Book Reviews 288

No. 4 Original Paper

Parker, D. and Turk, J. L.: Delay in the Develop

ment of the Allergic Response to Metals Fol

lowing Intratracheal Instillation 289 
Lin, T.-M.; Halbert, S. P., and Kiefer, D.: Cha racterization and Purification of PregnancyAssociated Plasma Protein B (PAPP-B) 294

Dziarski, R.: Immunosuppressive Effect of Staphylococcus aureus Peptidoglycan on Anti body Response in Mice 304

Desai, H. N.; Strashoon, J., and Wesley, A.: Cell-Mediated Immunity in Measles Using the Leucocyte Migration Test 312

Goihman-Yahr, M.; Convit, J.; RodríguezOchoa, G.; Aranzazu, N.; Villalba-Pimentel, L.; Ocanto, A., and Gomez, M. E. de: Signi ficance of Neutrophil Activation in Reactional Lepromatous Leprosy: Effects of Thalidomide in vivo and in vitro. Activation in Adju vant Disease 317

Larsson, E.-L. and Blomgren, H.: Evidence that Nonspecific Inhibitors Are Induced by So luble Products of Activated Human Lympho cytes 333

Igarashi, 1·L; Koizumi, K., and Muranaka, M.: Eliciting Antigenicities of Benzylpenicillin, Ampicillin and Carbenicillin Preparations Examined with the Reagin-Mediated Passive Cutaneous Anaphylaxis System 341 Løwenstein, H.: Characterization and Chemical Modification of Isolated Allergens from Horse Hair and Dandruff 349 Carswell, F. and Oliver, J.: Site of Respiratory Reaction in Allergic Rats Challenged via the Airways $\quad 358$

Lange, S.; Lindholm, L., and Holmgren, J.: Interaction of Cholera Toxin and Toxin Deri-vates with Lymphocytes. III. Modulating Effects in vivo by Cholera Toxin on the Graft-Versus-Host Reactivity of Lymphoid Cells: Suggested Inhibition of Suppressor Cells .... 364

Skvaril, F. and Gozze, I.: Anticomplementary Properties of Plasmin-Treated Human G Immunoglobulin and Its Components 375 Short Communication Løwenstein, H.: Immunological Partial Identity and in vitro Inhibitory Effect of Two Major Timothy Pollen Allergens to Whole Pollen Extract of Four Grasses $\quad 379$

Book Reviews 384

No. 5 Original Paper

Feigen, G.A.; Fraser, R.C.; Peterson, N.S., and Dandliker, W. B.: Sex Hormones and the Im 
mune Response. I. Host Factors in the Pro duction of Penicillin-Specific Antibodies in the Female Guinea Pig 385

König, W. and Czarnetzki, B. M.: Inactivation of Polymorphonuclear-Neutrophil Derived Eosinophil Chemotactic Factor by Human Serum 399

Sandilands, G. P.; Gray, K.; Reid, F., and An derson, J. R.: Demonstration of Fc Receptors on the Surface of B Lymphocytes 411 Symons, D.B.A. and Lay, C.A.: Immunoglobulin Biosynthesis in vitro after Stimulation of Pig Blood Lymphocytes with Mitogen 418 Birkeland, S. A.: In vitro Radiosensitivity of $\mathrm{Hu}$ man $\mathrm{T}$ and B Lymphocytes Evaluated Using Lymphocyte Transformation Tests and Ro sette Formation Tests 425

Hokland, M.; Hokland, P., and Heron, I.: Two Small Lymphocyte Subpopulations in Human Peripheral Blood. I. Purification and Surface Marker Profiles 435 Ross, J. W.; Smith, H., and Spicer, B. A.: 5Hydroxytryptamíne and Rat Passive Perito neal Anaphylaxis $\quad 444$

Masuzawa, Y.; Sawasa, S.; Sawasa, J., and Osa-wa, T.: Lymphocyte-Potentiating Factor from Human Peripheral Blood Adherent Cells ... 451

VI

Contents

Pommier de Santi, P.; Vervloet, D.; Vellieux, P.; Payan, H., and Charpin, J.: Electron-Micro scopic Study of the Anaphylactic Degranulation of Human Basophils from Atopic Sub jects 462

Pauwels, R.; Bazin, H.; Platteau, B., and Van Der Straeten, M.: Effect of Antigen Dose on the Secondary IgE Response in BN Rats .... 472

Short Communication

Merrick, J. M.; Zadarlik, K., and Milgrom, F.: Characterization of the Hanganutziu-Deicher (Serum-Sickness) Antigen as Gangliosides Containing N-Glycolylneuraminic Acid

No. 6 Original Paper

Søeberg, B.; Sumerska, T.; Binns, R. M., and

Balfour, B. M.: Contact Sensitivity in the Pig.

III. Induction by Intralymphatic Infusion of

DNP-Conjugated Cell Membranes and Sol 
uble Proteins, Free DNFB and Some Small

Molecular Weight Derivates 481

Feígen,G.A.; Fraser, R.C., and Peterson, N. S.:

Sex Hormones and the Immune Response. II.

Perturbation of Antibody Production by

Estradíol $\backslash 1 ß \quad 488$

Kennel, S. J.; Levy, R. L., and Spiegelberg, H. L.:

Quantitation of Antibodies to IgM, IgD and

/ $1 / 2$-Microglobulin in Antisera to Chronic

Lymphatic Leukemia Lymphocytes 498

Hurtado, J.; Márquez, V. E., and Vítolo, M. J.:

Inhibition of Allergic Reactions by a New An

tiallergic Drug, LC-6 (7 \&gt; ««s-2,3b,4,5,7,8b,9,-

10-Octahydronaphthol[1,2-c: 5,6-r] Dipy razo-

le). I. Inhibition of the Rat Reaginic Passive

Cutaneous Anaphylaxis 507

Hokland, P.; Hokland, M., and Heron, I.: Two

Small Lymphocyte Subpopulations in Human

Peripheral Blood. II. Functional Characteri

zation in vitro 514

Morito, T.; Nakamura, T.; Nakai, H.; Tanimo-

to, K.; Horiuchi, Y., and Juji, T.: Close As

sociation of Human Mixed Lymphocyte Cul

ture Antigen, la-Like Antigen and Fc Recep

tor 521

Levi, R.; Zavecz, J. H., and Ovary, Z.: IgE-Me-

diated Cardiac Hypersensitivity Reactions. An

Experimental Model 529

Lewis, F. A.; Heise, E. R., and Tulis, J.J.: De

layed Hypersensitivity to Hapten-Skin Protein

Conjugates in Guinea Pigs Sensitized to Ben-

zo(a)pyrene 535

Klostergaard, J.; Lisafeld, B. A.; Dunlap, B.;

Klein, E., and Holtermann, O. A.: Activation

of Neutrophilic Granulocytes by Products of

Human Lymphocytes 542

Kalveram, K.-J. and Forck, G.: Cross-Reactivity between Grass and Corn Pollen Antigens ... 549

Watanabe, N. and Ovary, Z.: Enhancement of IgE Antibody Production in AKR Mice .... 554

Ruddle, N. H.: Delayed Hypersensitivity to Soluble Antigens in Mice. I. Analysis in vivo .. . 560

Book Reviews 567

Author Index 569 